\title{
半滑舌鳎早期不同性别的形态差异及判别分析
}

\author{
王立萍 ${ }^{1,2}$, 叶 展 $^{1,2}$, 张亚群 ${ }^{2}$, 王巧欣 ${ }^{1,2}$, 李恒德 ${ }^{2}$
}

(1. 上海海洋大学, 水产科学国家级实验教学示范中心, 上海 201306;

2. 中国水产科学研究院生物技术研究中心, 北京 100141)

\begin{abstract}
摘 要: 为检验半滑舌鲳 (Cynoglossus semilaevis) 鱼苗 70 日龄时不同性别间的形态差异,对采集的 349 尾半 滑舌鳎幼苗准确鉴定性别, 并测量形态性状, 进行数据分布检验、方差分析、主成分分析和判别分析等。结果 显示, 所测各性别群组的形态指标数据均符合正态分布、方差齐性 $(P>0.05)$ 。对半滑舌鳎形态学性状的方 差分析和主成分分析表明, 雌、雄性别间差异主要集中在全长和体高等方面, 且雌鱼全长、体高平均值都大于 雄鱼和伪雄鱼。利用各项标准化指标进行判别分析, 雌性个体判别准确率为 $37 \%$, 雄性个体判别准确率为 $85 \%$, 伪雄鱼极不易判别且更接近雄性。研究表明, 对雄鱼的判别方法可满足生产中半滑舌鳎早期苗种性别 观测鉴定的要求, 从而达到提高苗种雌性率的目的。
\end{abstract}

关键词: 半滑舌鳎; 性别; 形态差异; 主成分分析; 判别分析

中图分类号: S 917

文献标志码: A

半滑舌鳎 (Cynoglossus semilaevis) 是我国近 海水域常见的一种暖温性大型底层鱼类, 其肉质 细嫩、营养丰富, 深受养殖户和消费者喜爱, 是我 国重要的海水经济鱼类。半滑舌鳎性别决定系 统为 $\left(\mathrm{ZW}+\mathrm{P}-\mathrm{ZZ}\right.$ 今 ) 型 ${ }^{[1-3]}$, 在苗种期, 部分遗传 雌性会逆转为表型雄性, 即伪雄鱼 (ZW 占), 这种 性别转变是不可逆的 ${ }^{[4]}$ 。半滑舌鳎成年雌性的 体质量是成年雄性的 $2 \sim 4$ 倍 ${ }^{[5]}$, 雄性和伪雄性 则存在着个体小、生长速度慢等缺点 ${ }^{[6]}$ 。虽然半 滑舌鳎刚孵化出的仔鱼的遗传雌、雄性别比例接 近 1: $1^{[7-9]}$, 但是由于性逆转现象, 导致雌性比例 过低, 从而增加了饲养和管理成本, 影响整体养 殖产量, 严重阻碍了半滑舌鳎养殖产业的发展。

在鱼类中, 具有明显两性性征的物种, 可利 用鯺条特征、生殖孔形态 ${ }^{[10]}$ 、产卵管 ${ }^{[11]}$ 、雄性体 表的追星 ${ }^{[12]}$ 和婚姻色有无 ${ }^{[13]}$ 等特征鉴别性别, 但对于外观特征不明显的物种,则可通过解剖观 察、组织切片 ${ }^{[14]}$ 、超声波 ${ }^{[15-16]}$ 、强光照射 ${ }^{[17]}$ 等
方法鉴定, 或从其基因组 DNA 中篮选出性别特 异标记基因,采用 PCR 技术准确鉴定鱼体遗传性 别, 如黄颡鱼 (Pelteobagrus fulvidraco $)^{[18]}$ 、半滑舌

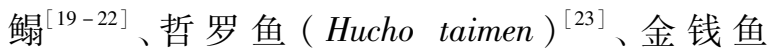
( Scatophagus argus) ${ }^{[24]}$ 、鳗 鲭 (Anguilla japonica $)^{[25]}$ 、翘嘴鳜 (Siniperca chuatsi $)^{[26]}$ 等。虽 然同批次半滑舌鳎成体的雌、雄、伪雄性体质量 差别较大, 较易辨别, 但在幼鱼期不同性别间差 异则较小, 不易辨别, 需要养殖较长时间后才能 依据体型大小差异基本辨别性别, 这会在很大程 度上增加养殖成本。在半滑舌鳎生产中, 鱼苗一 般在 70 日龄左右出售, 此时鱼苗全长约 $5 \mathrm{~cm}$ 左 右。为了获得客户认可, 育苗人员常常根据经 验, 将全长较短、体高较窄的貌似雄鱼个体淘汰, 以期提高所售苗种的雌性率。但由于这个时期 的鱼苗正处于性别分化时期,一些可能发育为伪 雄鱼的遗传雌鱼还未完成性别逆转过程, 这种经 验式的篮选方式是否可靠,还缺少相应的科学依

收稿日期: $2020-08-24$

基金项目：中国水产科学研究院基本科研业务费专项(2019A003,2020TD24)

作者简介：王立萍 (1996一), 女, 山东临沂人, 硕士研究生, 研究方向为水产生物技术。E-mail: lipingwang0123 @ 163. com

通信作者：李恒德,研究员。E-mail:hengde. li@ cafs. ac.cn 
据。

通过测量大量样本的鱼体形态和框架指标, 运用多元统计分析进行性别判定是一种较为简 便、实用、有效的方法。目前已有多种水产鱼类 通过测量鱼体各形态特征指标,运用主成分分 析、判别分析等方法较为准确地判别雌、雄。如 对大黄鱼 (Larimichthys crocea) 形态特征的主成分 分析和判别分析发现, 雌鱼较雄鱼变异大, 雌雄 个体间体长/体厚差异最大 ${ }^{[27]}$; 尧嘴鳜的全长和 体高对体质量的影响最大 ${ }^{[28]}$; 金钱鱼的雌雄差异 主要体现在头部和体型 ${ }^{[29]}$; 红鯺东方鲀 (Takifugu rubripes) 雄性较雌性体型宽、体周长 ${ }^{[30]}$ 。而目前 有关半滑舌鳎形态指标的研究很少, 且大都集中 于成鱼, 如利用相关性分析和通径分析方法判断 半滑舌鳎形态性状与个体体质量的关系 ${ }^{[31]}$, 以及 对半滑舌鲳的生长和形态参数方面进行研究 ${ }^{[32]}$ 等。因此, 本研究通过测量半滑舌鳎幼鱼雌、 雄、伪雄个体的形态学测量数据, 进行主成分分 析和判别分析, 检验通过形态特征对半滑舌鳎幼 鱼进行早期性别判定的可行性和准确性, 以期为 半滑舌鳎生产中幼鱼的性别鉴定提供科学的数 据支持和理论指导。

\section{1 材料与方法}

\section{1 实验材料}

半滑舌鳎样品 2019 年采集于天津某养殖场, 养殖水温 $23^{\circ} \mathrm{C}$ 左右, 随机捞取同批次的 70 日龄 半滑舌鳎苗种, 共计 349 尾, 作为测量分析样本。 由于部分半滑舌鲳雌性苗种在 50 120 日龄期间 会发生性逆转现象, 采用性腺组织切片的方法不 能准确判定生理性别, 故采用已知的半滑舌鲳性 别特异基因位点的方法来准确鉴定各样本生理 性别。对各样本分别取尾鯺提取基因组 DNA, 运 用半滑舌鳎的特异微卫星标记 SCAR 进行初步的 遗传性别鉴定 ${ }^{[20]}$, 区分出遗传雄性、遗传雌性, 由 于遗传雌性中可能含有会性逆转的生理性别为 伪雄性的个体, 之后通过半滑舌鳎遗传雌鱼 $\mathrm{Z}$ 染 色体上两个与性逆转相关的单核苷酸多态性 (SNP) 位点 ${ }^{[21-22]}$, 扩增测序以准确辨别伪雄性和 雌性。测序结果显示, 本次样品中雌性 116 尾、 雄性 180 尾、伪雄性 53 尾。雌性体长为 3.154 $7.959 \mathrm{~cm}$, 雄性体长为 $3.108 \sim 7.569 \mathrm{~cm}$, 伪雄性 体长为 $3.569 \sim 6.489 \mathrm{~cm}$ 。

\section{2 形态学性状测量}

取实验用鱼置于白色实验盘中, 旁边放置钢 尺, 逐尾标号标记, 水平拍照后, 采用 Motic Images Plus 2.0 软件测量全长 (吻端到尾鯺末端, FL)、 体高 (垂直于鱼体侧线最宽的部位, BH) 、尾巴角 度 $(\mathrm{CA})$ 、背部与水平线角度 $(\mathrm{DA})$ 等形态性状指 标, 精确至 $0.001 \mathrm{~cm}$ (图 1)。

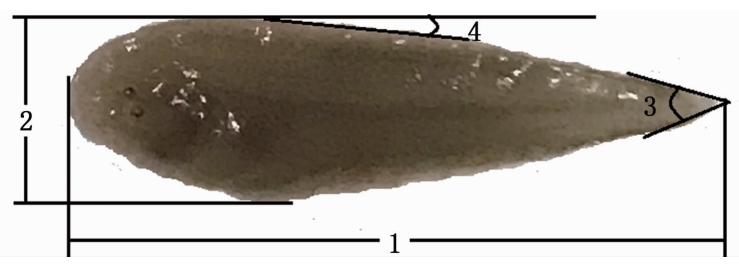

图 1 半滑舌鳎幼鱼各形态测量指标

Fig. 1 Morphological measurement indexes of Cynoglossus semilaevis seedling

注: 1 : 全长 $(\mathrm{FL}) ; 2$ : 体高 $(\mathrm{BH}) ; 3$ : 尾巴角度 $(\mathrm{CA}) ; 4$ : 背部与 水平线角度 $(\mathrm{DA})$

Note: 1 :full length(FL); 2 : body height (BH); 3 : caudal angle (CA); 4 : dorsal at a horizontal angle(DA)

\section{3 数据处理}

对收集到的 349 尾半滑舌鲳幼苗进行有效 可量性状测量并统计。为消除个体差异对形态 数据的影响, 也便于差异比较, 将测得的数据进 行整理及标准化, 考虑到数据连续性的问题, 把 角度值用正切转换为长度后再分析, 共得到 5 项 性状, 包括全长 $(\mathrm{FL}) 、$ 体高 $(\mathrm{BH})$ 、全长/体高 $(\mathrm{FL} / \mathrm{BH})$ 、尾部角度正切值 $(\mathrm{CT})$ 、背部与水平角 度正切值 (DT)。

\section{4 统计分析}

本研究应用 Excel 2016 及 R 软件( R4.0.0), 对样本各项形态测量数据进行处理分析。首先, 将 5 项性状数据进行分布检验, 明确各项数据是 否基本呈现正态分布, 并检验各项数据的方差齐 性。以 $P<0.05$ 表示差异显著, $P<0.01$ 表示差 异极显著。运用方差分析, 将样本的雌、雄、伪雄 3 种性别类别作为因子, 对各项形态测量数据进 行方差分析, 分析各性别间的差异显著性。之 后, 运用 $\mathrm{R}$ 中软件 princomp ( ) 函数对各项形态性 状进行主成分分析, 分析半滑舌鳎幼鱼不同性别 群体间的形态变异特征和程度。然后运用 $\mathrm{R}$ 软 件中 lda ( ) 函数进行 Fisher 判别分析, 根据各变 量对模型贡献的大小, 建立 70 日龄半滑舌鳎雌、 雄、伪雄个体判别方程式, 并根据所建立的方程, 对照鉴定的遗传性别信息, 检验判别的准确性。 


\section{2 结果与分析}

\section{1 半滑舌鳎幼鱼雌、雄、伪雄形态性状分析}

对 349 尾半滑舌鳎 70 日龄幼鱼雌、雄、伪雄 性别样本的形态测量性状进行统计 (表 1 )。经检 验, 样本中半滑舌鳎雌、雄、伪雄的各项测量数值 均为正态性分布, 且符合方差齐性 $(P>0.05)$ 。 雌性群体的全长 $(\mathrm{FL})$ 和体高 $(\mathrm{BH})$ 大于雄性, 全 长/体高 $(\mathrm{FL} / \mathrm{BH})$ 小于雄性, 且均有显著差异 $(P<0.05)$; 雌、伪雄群体间, 只在全长/体高 $(\mathrm{FL} / \mathrm{BH})$ 方面差异显著 $(P<0.05)$; 雄鱼和伪雄 鱼的形态性状则无显著差异。从以上统计可以 得知, 雌鱼的整体轮廓较同期雄鱼和伪雄鱼更为 宽大。

\section{2 主成分分析}

对半滑舌鳎早期幼鱼样本的 5 个形态测量 性状,运用 R 软件 princomp ( ) 函数进行主成分分 析, 结果表明, 前 3 个主成分 $(P C 1 、 P C 2 、 P C 3)$ 的 特征值较大, 它们的贡献率分别为 $39.011 \%$ 、 $27.976 \% 、 19.045 \%$, 累计贡献率达到 $86.032 \%$ (表 2)。其中 PC1 负荷量较大的有全长 (FL) 和 体高 $(\mathrm{BH})$, 主要反映半滑舌鳎整体轮廓大小特 征; PC2 负荷量较大的为尾巴角度正切值 (CT) 和 全长体高比 $(\mathrm{FL} / \mathrm{BH})$, 反映了鱼体的宽度大小以 及尾巴角度的影响; PC3 主要负荷量较大的为背 部与水平线角度 $(\mathrm{DT})$ 和全长体高比 $(\mathrm{FL} / \mathrm{BH})$, 主要反映视觉上鱼体的长宽比。

根据主成分分析的结果,绘制半滑舌鳎早期 个体样本的主成分得分散点图。如图 2 所示, 尽 管分散不明显,但仍表现出分离态势, 雌性个体 整体得分较高, 趋于图的上部分, 雄性个体得分 趋于图的下部,伪雄性个体分散于图片中部。

\section{3 判别分析}

由于主成分分析只能揭示半滑舌鳎不同性 别群体间形态变异的特征和程度, 无法判别单一 半滑舌鳎的性别, 因此需要进行判别分析。进一 步对 349 尾半滑舌鳎个体的 5 项形态测量性状进 行判别分析, 根据各变量对模型的贡献率, 所建 立的判别模型方程为:

$$
\mathrm{LD}_{1}=-1.395 \mathrm{FL}+1.634 \mathrm{BH}+1.624 \mathrm{CT}-
$$

7. $298 \mathrm{DT}+4.126 \mathrm{FL} / \mathrm{BH}$

$\mathrm{LD}_{2}=-8.902 \mathrm{FL}+35.636 \mathrm{BH}-1.696 \mathrm{CT}+$ $18.293 \mathrm{DT}+13.238 \mathrm{FL} / \mathrm{BH}$

第一判别式 $\mathrm{LD}_{1}$ 对区分雌、雄、伪雄的贡献 率大小为 0.8137 , 第二判别式 $\mathrm{LD}_{2}$ 对区分各性 别组的贡献率为 0.1863 , 误判率为 0.4355 。判 别函数的显著性检验显示 $P<0.01$, 达到极显著 水平。利用所建立的判别方程, 对 349 尾半滑舌 鳎雌、雄、伪雄个体性别进行判别检验。其中, 雄 性个体判别准确率较高, 为 $85.000 \%$; 雌性个体 判别准确率较低, 为 $37.069 \%$; 伪雄鱼个体判别 准确率极低, 为 $1.887 \%$,伪雄鱼形态特征不明显 且更易判为雄鱼; 综合判别准确率为 $56.447 \%$ (表3)。

\section{3 讨论}

分析不同性别鱼体间的形态特征差异,建立 形态指标体系, 进行雌雄差异判别, 是一种可行、

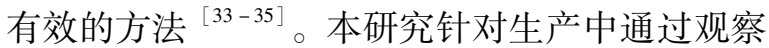
半滑舌鳎幼鱼形态来判断性别的科学性问题, 建 立了 3 种性别判别模型方程进行判别检验, 相关 结果对能否通过体型差异淘汰雄性和伪雄性个 体, 以提高商品苗的雌性率提供了重要的理论依 据。

表 1 半滑舌鳎雌、雄、伪雄形态性状的参数统计 $(N=349)$

Tab. 1 Statistics of morphological characters of female, male and pseudomale in Cynoglossus semilaevis

\begin{tabular}{cccccc}
\hline & FL & BH & CT & DT & FL/BH \\
\hline 雌 Female & $5.099^{\mathrm{a}}(0.081) \mathrm{cm} 1.368^{\mathrm{a}}(0.020) \mathrm{cm}$ & $0.743^{\mathrm{a}}(0.015)$ & $0.081^{\mathrm{a}}(0.002)$ & $3.726^{\mathrm{a}}(0.022)$ \\
雄 Male & $4.862^{\mathrm{b}}(0.056) \mathrm{cm} 1.279^{\mathrm{b}}(0.014) \mathrm{cm}$ & $0.757^{\mathrm{a}}(0.012)$ & $0.078^{\mathrm{a}}(0.002)$ & $3.809^{\mathrm{b}}(0.018)$ \\
伪雄 Pseudomale & $5.005^{\mathrm{ab}}(0.088) \mathrm{cm} 1.308^{\mathrm{ab}}(0.024) \mathrm{cm}$ & $0.726^{\mathrm{a}}(0.021)$ & $0.085^{\mathrm{a}}(0.004)$ & $3.840^{\mathrm{b}}(0.040)$ \\
方差齐性 $(\mathrm{P})$ Levene test & 0.234 & 0.355 & 0.737 & 0.093 & 0.372 \\
\hline
\end{tabular}

注: $\mathrm{FL}$ : 全长; $\mathrm{BH}$ : 体高; $\mathrm{CT}$ : 尾部角度正切值; $\mathrm{DT}$ : 背部与水平角度正切值; $\mathrm{FL} / \mathrm{BH}$ : 全长/体高。同列数据中不同上标字母表示差异显著 $(P<0.05)$, 表中形态性状数据均为均值 (标准误) 形式

Note:FL:full length; BH: body height; CT: caudal angle tangent; DT: dorsal at a horizontal angle tangent; FL/BH: full length/body height. Different superscript letters in the same column mean significant differences $(P<0.05)$ 


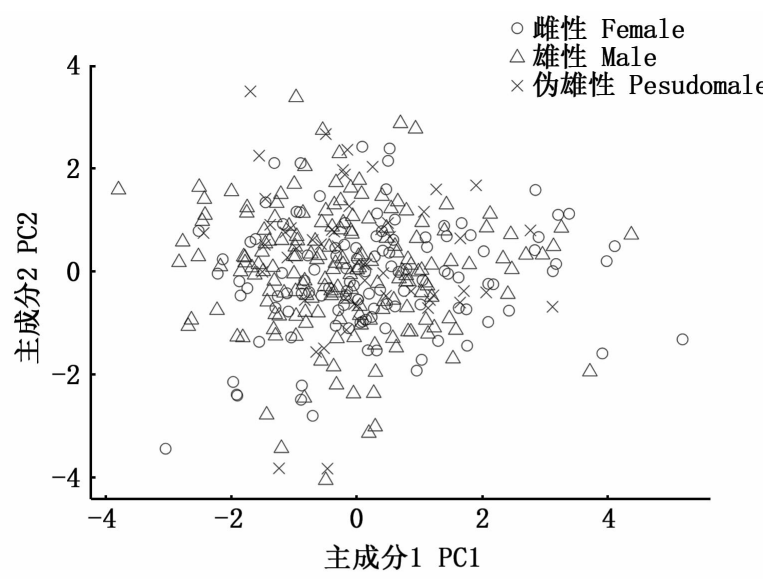

(a)

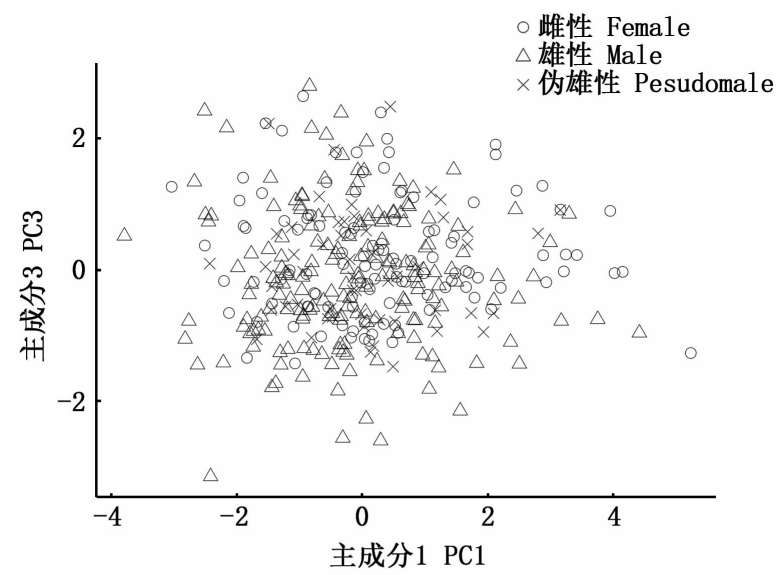

(b)

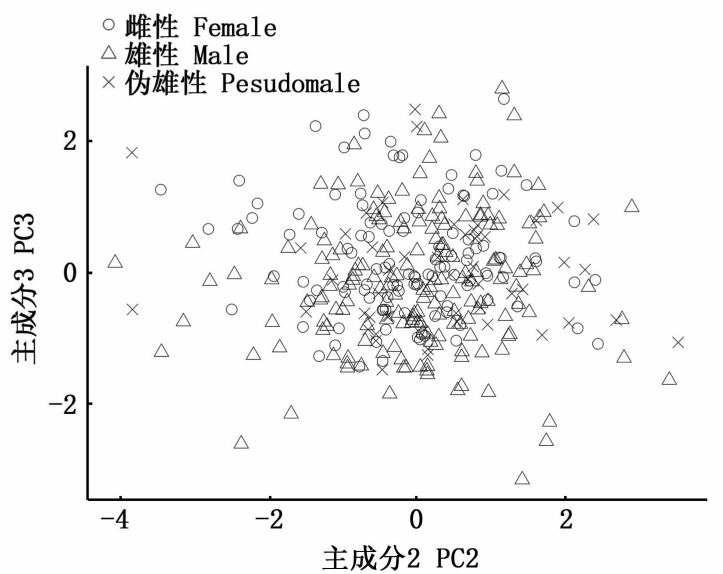

(c)

图 2 半滑舌鳎形态性状主成分分析

Fig. 2 Distribution of $\boldsymbol{C}$. semilaevis body size traits on principal component

注: a. 半滑舌鲳形态性状在 PC1-PC2 上的分布; b. 半滑舌鲳形态性状在 PC1-PC3 上的分布; c. 半滑舌鲳形态性状在 PC2-PC3 上的 分布

Note: a. distribution of principal component 1 and 2 of C. semilaevis; b. distribution of principal component 1 and 3 of C. semilaevis; c. distribution of principal component 2 and 3 of C. semilaevis

表 2 主成分贡献率及各指标负荷量

Tab. 2 Contribution rate of principal components and load capacity of each index

\begin{tabular}{|c|c|c|c|}
\hline \multirow{2}{*}{ 性状 Traits } & \multicolumn{3}{|c|}{ 主成分 Principal components } \\
\hline & 1 & 2 & 3 \\
\hline 全长 FL & 0.704 & 0.105 & 0.005 \\
\hline 体高 BH & 0.685 & -0.155 & 0.228 \\
\hline 尾巴角度正切值 CT & -0.075 & -0.648 & -0.088 \\
\hline 背部与水平角度 DT & -0.159 & 0.381 & 0.815 \\
\hline 全长/体高 FL/BH & 0.070 & 0.633 & -0.526 \\
\hline $\begin{array}{c}\text { 贡献率/\% } \\
\text { Contribution rate }\end{array}$ & 39.011 & 27.976 & 19.045 \\
\hline $\begin{array}{c}\text { 累计贡献率/\% } \\
\text { Cumulative contribution rate }\end{array}$ & 39.011 & 66.987 & 86.032 \\
\hline
\end{tabular}

本研究发现, 雌性幼鱼整体轮廓较雄性和伪 雄性大, 且腹部较宽, 而雄鱼和伪雄鱼在形态上
较为相似, 这与其成体的外部形态也较为一 致 ${ }^{[7]}$ 。雌、雄、伪雄性个体间存在的这种形态差 异,与其体内性激素水平、性成熟时间有关,卵巢 和精巢的细胞学分化通常不同步,雄鱼较雌鱼成 熟所需时间短 ${ }^{[36]}$ 。

本研究应用主成分分析方法, 对可能反映半 滑舌鳎不同性别形态差异的多维空间相关变化 的数据集, 降维转化为少量且相互独立的新综合 指标, 从而简化数据结构, 并包含原指标中的主 要信息。由主成分分析结果可知, 提取的 3 个主 成分 $(P C 1 、 P C 2 、 P C 3)$ 的累计贡献率达 $86.032 \%$ ， 表明该方法既可保留变量间的大部分信息, 又能 够保证较高的预测准确度。根据主成分分析得 分情况可知,对性别分离作用较大的主要是全长、 
表 370 日龄半滑舌鳎性别判别结果

Tab.3 Discriminant results of sexual discrimination of 70 days Cynoglossus semilaevis

\begin{tabular}{|c|c|c|c|c|c|c|}
\hline \multirow[b]{2}{*}{ 性别 Sex } & \multirow[b]{2}{*}{ 尾数 Number } & \multicolumn{3}{|c|}{ 判别结果 Discrimination results } & \multirow{2}{*}{$\begin{array}{c}\text { 判别准确率/\% } \\
\text { Discriminant } \\
\text { accuracy }\end{array}$} & \multirow{2}{*}{$\begin{array}{c}\text { 综合判别率/\% } \\
\text { Comprehensive } \\
\text { dicriminant rate }\end{array}$} \\
\hline & & $\begin{array}{c}\text { 雌性 } \\
\text { Female }\end{array}$ & $\begin{array}{l}\text { 雄性 } \\
\text { Male }\end{array}$ & $\begin{array}{c}\text { 伪雄性 } \\
\text { Pseudomale }\end{array}$ & & \\
\hline 雌 Female & 116 & 43 & 73 & 0 & 37.069 & \\
\hline 雄 Male & 180 & 27 & 153 & 0 & 85.000 & 56.447 \\
\hline 伪雄 Pseudomale & 53 & 8 & 44 & 1 & 1.887 & \\
\hline
\end{tabular}

体高及其比值方面, 表明半滑舌鳎雌、雄、伪雄性 个体间的差异主要集中在整体轮廓大小的指标 方面,这与其形态性状差异显著性分析的结果相 符, 可为半滑舌鳎幼鱼性别判别、篮选培育高雌 群体提供重要理论参考。

同时,判别分析是一种实用性很强的统计判 别和分组技术,已有多种鱼类通过本方法有效区 分不同性别群体, 如长江口鳗鲡的雌雄判别准确 率为 $88.59 \%{ }^{[37]}$, 金钱鱼的雌雄综合判别准确率 为 $85.96 \%{ }^{[29]}$, 红鯺东方鲀的性别综合判别准确 率为 $81.90 \%{ }^{[30]}$, 河川沙塘鳢 (Odontobutis potamophila) 雌雄综合判别准确率为 $71.0 \%{ }^{[33]}$, 翘嘴红鮊 (Eryghroculter ilishaeformis) 群体的识别 正确率达 $91.0 \%{ }^{[38]}$, 趐嘴鲼雌、雄综合判别准确 率为 $61.7 \%$ 。本研究的检验结果显示, 半滑 舌鳎 70 日龄幼鱼雄性判别准确率为 $85 \%$, 可篮 选淘汰大部分雄鱼, 雌性个体判别准确率为 $37 \%$, 伪雄鱼个体易判为雄鱼, 伪雄鱼的生长速 度虽较雄鱼稍快, 但较正常雌鱼慢, 由于需要淘 汰伪雄鱼, 因此尽管其判定准确性低,但是并不 影响实际应用。本研究显示, 雌性判别率较低, 相当一部分雌性个体存在易错判为雄性个体而 被淘汰掉, 从而造成一定程度的苗种浪费, 但由 于生理雄鱼的判别率较高, 因而更容易被淘汰 掉。所以总体上看, 根据形态学性状建立的判别 方法可在 70 日龄左右区别并淘汰雄鱼及伪雄 鱼, 从而在一定程度上提高苗种的雌性率, 但同 时也会把一部分雌鱼淘汰掉。

综上,本研究利用 70 日龄半滑舌鲳雌、雄、 伪雄性别的形态差异建立判别模型, 其雄鱼判别 准确率达 $85 \%$, 较之前通过强光照射方法肉眼判 断雄鱼 $54.7 \%$ 的准确率 ${ }^{[17]}$ 有了较大提高, 为生 产上通过观察幼鱼形态指标、篮选淘汰雄性个 体、提高商品苗的雌性率提供了科学依据。各性 别鱼体在生长过程中, 由于体型的增大, 全长/体 高的比值会随之变化, 所以不易固定量化。但对
于同一批次鱼而言, 大致符合雄鱼比雌鱼全长较 短、体高较窄的特点。早期淘汰雄鱼和伪雄鱼会 使一定比例的䧳鱼淘汰掉。由此建议半滑舌鳎 早期苗种的䇻选时间进行适当的推迟, 如 120 日 龄,此时鱼体性别已完全分化,但同时也会增加 苗期的养殖成本, 因此在实际生产中需综合权 衡, 以达到养殖效益最大化。

\section{参考文献:}

１１］周丽青,杨爱国,柳学周, 等. 半滑舌鳎染色体核 型分析 $[\mathrm{J}]$. 水产学报, $2005,29(3): 417-419$.

ZHOU L Q, YANG A G, LIU X Z, et al. The karyotype of the tongue fish Cynoglossus semilaevis [J]. Journal of Fisheries of China, 2005,29(3): $417-419$.

[2] CHEN S, ZHANG G, SHAO C, et al. Wholegenome sequence of a flatfish provides insights into $\mathrm{ZW}$ sex chromosome evolution and adaptation to a benthic lifestyle $[\mathrm{J}]$. Nature Genetics, 2014, 46 (3) $: 253-260$.

[3] 张全启,王旭波,刘金相. 半滑舌鳎性别决定和性 别控制育种研究进展与展望 $[\mathrm{J}]$. 中国海洋大学 学报 (自然科学版),2019,49(10):43-53.

ZHANG Q Q, WANG X B, LIU J X. Progress and prospects of sex determination and sex control in Chinese tongue sole Cynoglossus semilaevis $[\mathrm{J}]$. Periodical of Ocean University of China, 2019, 49 (10): $43-53$.

[4] 季相山, 陈松林, 马洪雨, 等. 半滑舌鲳养殖群体 中自然性逆转伪雄鱼的发现 $[\mathrm{J}]$. 水产学报, 2010,34 (2) :322 - 327 .

JI X S, CHEN S L, MA H Y, et al. Natural sex reversal of female Cynoglossus semilaevis in rearing populations $[\mathrm{J}]$. Journal of Fisheries of China, 2010,34 (2):322 - 327.

[5] CHEN S L, TIAN Y S, YANG J F, et al. Artificial gynogenesis and sex determination in half-smooth tongue sole (Cynoglossus semilaevis) $[\mathrm{J}]$. Marine Biotechnology, 2009,11(2) :243 - 251 . 
［6］孟田湘, 任胜民. 渤海半滑舌鳎的年龄与生长 [J]. 海洋水产研究, 1988, 9(2) : 173-183.

MENG T X, REN S M. Age and growth of Cynoglossus semilaevis gunther in the Bohai sea $[\mathrm{J}]$. Marine Fisheries Research, 1988, 9 (2): 173 183.

[7] 李 虎, 陈四清, 刘海金, 等. 半滑舌鳎养殖群体 的性比与雌雄形态差异比较 $[\mathrm{J}]$. 水产学报, $2012,36(9): 1331-1336$.

LI H, CHEN S Q, LIU H J, et al. Study on sex ratio and comparison of morphological variation between genders of cultured half-smooth tongue sole (Cynoglossus semilaevis) [ $\mathrm{J}]$. Journal of Fisheries of China, 2012,36(9):1331 - 1336.

[8] 梁 卓, 陈松林, 张 静, 等. 半滑舌鰨养殖群体 雌雄比例与自然性逆转率 $[\mathrm{J}]$. 中国水产科学, 2013,20 (1):44 - 49 .

LIANG Z, CHEN S L, ZHANG J, et al. Analysis of the female ratio and natural sexual reversal ratio in cultured half-smooth tongue sole families $[\mathrm{J}]$. Journal of Fishery Sciences of China, 2013,20(1) : $44-49$.

[9] 张 伟. 对半滑舌鳎养殖技术及雌雄比例状况的 研究 $[\mathrm{J}]$. 江西水产科技, 2015(4):18-22.

ZHANG W. Study on the breeding technology and the ratio of male and female of half-smooth tongue sole $[\mathrm{J}]$. Jiangxi Fishery Science and Technology, 2015 (4):18-22.

[10］蔡永祥,陈友明,陈校辉, 等. 江黄颡 (Pelteobagrus vachelli) 和拟鲿 (Pseudobagrus ussuriensis) 杂交 $\mathrm{F}_{1}$ 代形态差异 $[\mathrm{J}]$. 湖泊科学, 2011,23 (2) : 264 270.

CAI Y X, CHEN Y M, CHEN X H, et al. Morphometric differences of the hybrid $F_{1}$ of Pelteobagrus vachelli $\times$ Pseudobagrus ussuriensis [J]. Journal of Lake Sciences, 2011,23(2) :264 270.

[11] 李润潼. 鱼类的性别 $[\mathrm{J}]$. 生物学通报, 1993,28 (11) $: 8-9$.

LI R T. Sex of fish $[\mathrm{J}]$. Bulletin of Biology, 1993, 28(11):8-9.

[12] 董武子, 王 涛, 马 力, 等. 秦巴山区多鳞白甲 鱼人工繁殖试验 $[\mathrm{J}]$. 畜牧兽医杂志, 2016,35 (3) :27 - 30.

DONG W Z, WANG T, MA L, et al. Artificial reproduction of Varicorhinus macrolepis in Qin-Ba mountains $[\mathrm{J}]$. Journal of Animal Science and Veterinary Medicine, 2016,35(3):27 - 30.
[13］唐富江, 王继隆, 刘 伟. 乌苏里江大麻哈鱼 ( 9$)$ 婚姻色差异的生态指征意义 $[\mathrm{J}]$. 水产学杂志, 2012,25 (4) : 46 - 49,55.

TANG F J, WANG J L, LIU W. Ecological implication of nuptial colors in chum salmon (Oncorhynchus keta) in Chinese Ussuri River [J]. Chinese Journal of Fisheries, 2012,25(4) :46 - 49, 55.

[14] 宁静允. 半滑舌鳎早期性腺发育的研究 [D]. 保 定:河北大学, 2010 .

NING J Y. Study on the development of gonad at early stages in Cynoglossus semilaevis [D]. Baoding: Hebei University ,2010.

[15] BLYTHE B, HELFRICH L A, BEAL W E, et al. Determination of sex and maturational status of striped bass (Morone saxatilis) using ultrasonic imaging $[\mathrm{J}]$. Aquaculture, $1994,125(1 / 2)$ : 175 184.

[16] 王 斌, 于冬梅, 师 伟, 等. 利用超声波技术鉴 定幼龄鲟鱼的性别 $[\mathrm{J}]$. 动物学杂志, 2009,44 (2) $: 57-63$.

WANG B, YU D M, SHI W, et al. Determination of sex and maturity by using ultrasonography in largescale cultivation of young sturgeon $[\mathrm{J}]$. Chinese Journal of Zoology, 2009,44(2):57 - 63 .

[17] 宋 超, 蒋 丽, 王景伟, 等. 半滑舌鲳性逆转的 遗传特性研究 $[\mathrm{J}]$. 生物技术通报, 2015,31(3): $207-212$.

SONG C, JIANG L, WANG J W, et al. Studies on genetic features of sex reversal in Cynoglossus semilaevis $[\mathrm{J}]$. Biotechnology Bulletin, 2015,31 (3) : $207-212$.

[18] 辛文婷, 孙中武, 尹洪滨, 等. 黄颡鱼雌雄差异的 SRAP 标记 $[J]$. 东北林业大学学报, 2009,37 (5) : 112 - 113 .

XIN W T, SUN Z W, YIN H B, et al. Identification of sex-associated SRAP marker in Peltebagrus fulvidraco $[\mathrm{J}]$. Journal of Northeast Forestry University, 2009,37 (5):112 - 113.

[19] CHEN S L, DENG S P, MA H Y, et al. Molecular marker-assisted sex control in half-smooth tongue sole (Cynoglossus semilaevis) [ J ]. Aquaculture, $2008,283(1-4): 7-12$.

[20] 刘 洋, 陈松林, 高峰涛, 等. 半滑舌鳎性别特异 微卫星标记的 SCAR 转化及其应用 $[\mathrm{J}]$. 农业生 物技术学报, 2014, 22(6):787-792.

LIU Y, CHEN S L, GAO F T, et al. SCAR transformation of sex-specific SSR marker and its 
application in half-smooth tongue sole (Cynoglossus semilaevis ) [ J ]. Journal of Agricultural Biotechnolog, 2014, 22(6) :787 - 792 .

[21 ] JIANG L, LI H D. Single locus maintains large variation of sex reversal in half-smooth tongue sole ( Cynoglossus semilaevis ) [ J ]. G3: Genes, Genomes, Genetics, 2017,7(2) :583 - 589.

[22] CUI Y, WANG W F, MA L Y, et al. New locus reveals the genetic architecture of sex reversal in the Chinese tongue sole (Cynoglossus semilaevis) $[\mathrm{J}]$. Heredity, 2018,121(4) :319-326.

[23] 张超, 佟广香, 匡友谊, 等. 利用 AFLP 技术筛 选与哲罗鱼 Hucho taimen (Pallas) 性别相关的分子 标记 $[J]$. 东北农业大学学报, 2010,41 (5) :96103.

ZHANG C, TONG G X, KUANG Y Y, et al. Screen sex-related DNA markers in Hucho taime (Pallas) using AFLP $[\mathrm{J}]$. Journal of Northeast Agricultural University, 2010,41 (5):96-103.

[24] 向 玲. 金钱鱼性别特异分子标记的篮选及雌雄 群体遗传多样性分析 [D]. 湛江: 广东海洋大学, 2015.

XIANG L. The isolation of sex-specific molecular marker and the analysis of genetic structure between males and females in Scatophagus argus [D]. Zhanjiang: Guangdong Ocean University, 2015.

[25] 张利娜. 长江口降海鳗鲡雌雄判别方法及雌性特 异 SCAR 标记的建立 $[D]$. 上海: 上海海洋大学, 2017.

ZHANG L N. SCAR marker in migratory eels (Anguilla japonica) collected at the Yangtze River [D]. Shanghai: Shanghai Ocean University, 2017.

[26］周云红, 葛婉仪, 夏 星, 等. 鳜雌雄表型差异及 性别相关标记筛选 $[\mathrm{J}]$. 安徽农业大学学报, $2020,47$ ( 1$): 30-35$.

ZHOU Y H, GE W Y, XIA X, et al. Phenotypic difference between the males and females and screening the sex-specific molecular marker in Siniperca chuatsi $[\mathrm{J}]$. Journal of Anhui Agricultural University, 2020,47 (1) :30 - 35.

[27] 谌 微,王盼盼, 肖世俊, 等. 大黄鱼形态指标体 系及雌雄差异分析 $[\mathrm{J}]$. 集美大学学报 (自然版), 2014,19 (6): 401 - 408.

CHEN W, WANG P P, XIAO S J, et al. Analysis of morphological index system and sexual differences of large yellow croaker (Larimichthys crocea) $[\mathrm{J}]$. Journal of Jimei University (Natural Science), 2014 , 19 (6) : $401-408$.
[28] 董浚键, 孙成飞, 田园园, 等. 尧嘴鲭主要形态性 状与体重的相关性及雌雄形态性状差异分析 $[\mathrm{J}]$. 渔业科学进展, 2018,39(2):76-84.

DONG J J, SUN C F, TIAN Y Y, et al. Correlation analysis of the main morphological traits and body weight of mandarin fish ( Siniperca chuatsi) and morphological traits between males and females $[\mathrm{J}]$. Progress in Fishery Sciences, 2018,39(2) :76-84.

[29] 吴 波,张敏智, 邓思平, 等. 金钱鱼雌雄个体的 形态差异分析 $[\mathrm{J}]$. 上海海洋大学学报, 2014,23 (1) :64-69.

WU B, ZHANG M Z, DENG S P, et al. Analysis of morphological index and discrimination of male and female Scatophagus argus [J]. Journal of Shanghai Ocean University, 2014, 23(1)64-69.

[30］岳 亮, 王新安, 马爱军, 等. 红鯺东方鲀 (Takifugu rubripes) 雌、雄个体的形态特征比较 $[\mathrm{J}]$. 渔业科 学进展, 2016, 37 (1):30 - 35.

YUE L, WANG X A, MA A J, et al. Comparison of the morphological traits between male and female individuals of Takifugu rubripes $[\mathrm{J}]$. Progress in Fishery Sciences, 2016, 37(1):30 - 35.

[31] 刘 峰, 陈松林, 刘肖峰, 等. 半滑舌鳎 3 个形态 性状与体质量的相关及通径分析 $[\mathrm{J}]$. 海洋学报, 2015,37 (4) :94 - 102.

LIU F, CHEN S L, LIU X F, et al. Correlation and path coefficient analysis for body mass and three morphometric traits in the half-smooth tongue sole (Cynoglossus semilaevis) [ J ]. Haiyang Xuebao, 2015,37 (4):94 - 102.

[32］郑忠明, 倪海儿. 东海半滑舌鳎的生长与形态参 数研究 $[\mathrm{J}]$. 宁波大学学报 (理工版), 2000,13 (2) $: 21-24$.

ZHENG Z M, NI H E. Study on growth and features of Cynoglossus semilaevis [ J]. Journal of Ningbo University (Natural Science \& Egineering) , 2000, 13(2):21 - 24 .

[33] 张宏叶, 陈树桥, 王 涛, 等. 河川沙塘鳢的形态 指标体系及雌雄差异分析 $[\mathrm{J}]$. 江苏农业科学, $2018,46(6): 138-142$.

ZHANG $\mathrm{H} \mathrm{Y}$, CHEN $\mathrm{S}$ Q, WANG $\mathrm{T}$, et al. Analysis of morphological index system and sexual differences of Odontobutis potamophila $[\mathrm{J}]$. Jiangsu Agricultural Sciences, 2018,46(6) :138 - 142.

[34] 周惠强, 李 芬, 舒 琥, 等. 大刺鲀雌雄个体形 态差异分析 $[\mathrm{J}]$. 广东海洋大学学报, 2019,39 (1) $: 1-6$.

ZHOU H Q, LI F, SHU H, et al. Analysis on 
morphological indexs and discrimination of male and female Mastacembelus armatus [ J ]. Journal of Guangdong Ocean University, 2019,39(1):1 - 6 .

[35］武兆文,郑 翔,张佳佳, 等. 杂交黄颡鱼“黄优 1 号”形态指标体系的建立及雌雄差异判别 $[\mathrm{J}]$. 海 洋渔业, 2019,41(5) :578-588.

WU Z W, ZHENG X, ZHANG J J, et al. Establishment of morphological index system of hybrid yellow catfish “Huangyou-1” (Pelteobagrus vachelli $\hat{o} \times P$. fulvidraco $q$ ) and discriminantion of male and female differences $[\mathrm{J}]$. Marine Fisheries, $2019,41(5): 578-588$.

[36] 宋 超. 半滑舌鳎性别分化的遗传特性研究 [D]. 兰州: 甘肃农业大学, 2015.

SONG C. Studies on genetic features of gonadal differentiation in half-smooth tongue sole( Cynoglossus semilaevis ) [ D ]. Lanzhou: Gansu Agricultural
University, 2015.

[37］郭弘艺, 魏 凯, 谢正丽, 等. 长江口银色鳗的形 态指标体系及其雌雄鉴别 $[\mathrm{J}]$. 水产学报, 2011 , $35(1): 1-9$.

GUO H Y, WEI K, XIE Z L, et al. Analysis of morphological index system and discrimination of male and female silver eels (Anguilla japonica) collected at the Yangtze River Estuary $[\mathrm{J}]$. Journal of Fisheries of China, 2011,35(1):1 - 9.

[38］安 丽, 孟庆否, 张龙岗, 等. 尧嘴红鮊雌雄个体 的形态差异分析 $[J]$. 淡水渔业, 2017,47 (2) :36 -41 .

AN L, MENG Q L, ZHANG L G, et al. Analysis of morphological indexes and discrimination of male and female Eryghroculter ilishaeformis [J]. Freshwater Fisheries, 2017,47 (2) : $36-41$. 


\title{
Morphological differences and discriminant analysis of different sex in early stage of Cynoglossus semilaevis
}

\author{
WANG Liping ${ }^{1,2}$, YE Zhan ${ }^{1,2}$, ZHANG Yaqun ${ }^{2}$, WANG Qiaoxin ${ }^{1,2}$, LI Hengde ${ }^{2}$ \\ (1. National Demonstration Center for Experimental Fisheries Science Education, Shanghai Ocean University, Shanghai \\ 201306, China; 2. Centre for Applied Aquatic Genomics, Chinese Academy of Fishery Sciences, Beijing 100141, China)
}

\begin{abstract}
In order to test the method of culling male and pseudomale seedlings of Cynoglossus semilaevis at 70 dph according to morphological differences between different sex to improve the female percentage in the population, a total of 349 seedlings of Cynoglossus semilaevis at $70 \mathrm{dph}$ were randomly collected from a farm in Tianjin in 2019. Genomic DNA were extracted from the tail fin of each sample, and the sex specific gene loci of Cynoglossus semilaevis were used to accurately identify the genetic and physiological sex of each sample. In order to eliminate the influence of individual differences on the data and facilitate the difference comparison and data continuity, the data were standardized, and the angle value was converted into length by tangent for analysis. A total of 5 morphological traits were obtained, including full length (FL), body height (BH), full length/body height ( FL/BH), caudal angle tangent ( CT), dorsal at a horizontal angle tangent (DT). Principal component analysis was performed to analyze the morphological variation among different gender groups of Cynoglossus semilaevis. The discriminant equations of Cynoglossus semilaevis at $70 \mathrm{dph}$ were established for female, male and pseudomale with linear discriminant analysis, and the accuracy of discriminant equations were verified according to the genetic gender information of the established equations. Results showed that the morphological traits of each gender group were normally distributed, and homogeneous in variance $(P>0.05)$. The analysis of variance and principal component analysis of morphological characters of Cynoglossus semilaevis showed that the differences between males and females were mainly concentrated in body length and body height, and the mean values of body length and body height of females were higher than those of males and pseudomales. The discriminant accuracy of females and males was $37 \%$ and $85 \%$, respectively by using various standardized indicators. It was very difficult to discriminate pseudomales, because they were close to males. Results showed that the accuracy of male identification was relatively high, which could meet the requirements of early gender observation and identification of seedlings to improve the female percentage of Cynoglossus semilaevis. Therefore, it is suggested to postpone the culling of seedlings of Cynoglossus semilaevis, such as at $120 \mathrm{dph}$, when the sex of the fish is completely differentiated. But it will increase the breeding costs simultaneously, therefore, tradeoff should be considered comprehensively to maximize the benefits.
\end{abstract}

Keywords: Cynoglossus semilaevis; sex; morphological difference; principal component analysis; discriminant analysis 